\title{
High-pressure phase equilibrium data for the pseudo-binary systems propane + L-lactide at different ethanol to L-lactide molar ratios
}

\author{
J. P. BENDER ${ }^{1}$, D. Z. FLORES ${ }^{2}$, M. V. TRÊS ${ }^{2}$, J. V. OLIVEIRA ${ }^{3}$ e S. R. S. FERREIRA ${ }^{3}$ \\ ${ }^{1}$ Universidade Federal da Fronteira Sul - Campus Erechim, Departamento de Engenharia \\ Ambiental \\ ${ }^{2}$ Universidade Regional Integrada do Alto Uruguai e das Missões - Campus Erechim, \\ Departamento de Engenharia de Alimentos \\ ${ }^{3}$ Universidade Federal de Santa Catarina, Departamento de Engenharia Química e Engenharia de \\ Alimentos \\ E-mail para contato: joao.bender@uffs.edu.br
}

\begin{abstract}
The biopolymer poly(L,L-lactide) (PLLA) have received increased attention due to their potential application in the medicine and food industries. The PLLA have very promising properties - bioresorbable and biocompatible properties in the human body - and are easily synthesized from components available from renewable sources. This polymer can be manufactured by different polymerization routes, amoung which we highlight the enzyme-catalyzed ringopening polymerization of L,L-lactide in compressed fluid. The aim of this work was to report the phase equilibrium data of the pressurized propane $(1)+\mathrm{L}, \mathrm{L}$ lactide(2) at two ethanol to monomer molar ratios (9:1 and 7:1). The phase equilibrium experiments were conducted in a high pressure variable-volume view cell employing the static synthetic method. The liquid-vapor equilibrium for the pseudo-binary systems was determined in the temperature range 323-353K and pressure up to $3.04 \mathrm{MPa}$. For the systems investigated the liquid-vapor equilibrium (VLE) were visually recorded. It was observed that an increase in temperature or in propane concentration led to pronounced raise in transition pressure values. While an increase in the ethanol to L,L-lactide molar ratio leads to a reduction in the pressure transition. In addition, a reduction in the concentration of ethanol in the system complicates the solubility of the system.
\end{abstract}

\section{INTRODUCTION}

The lactides monomers, a cyclic dimer of lactic acid, are formed by combination two lactic acid molecules and gives rise to L-Lactide or L,L-Lactide, D-lactide or D,D-Lactide, and mesolactide or L,D-lactide (an L-lactic acid and D-lactic acid molecule) (Gupta e Kumar, 2007; Avérous, 2008). These monomers are used for the preparation of polylactide - a biologically decomposable polymer, bioresorbable and biocompatible properties in the human body - which have received attention due to their potential applications in the medicine and food industries (Chen et al., 2003). The interest in L,L-lactide instead of D-lactide is related to the need of the industry in obtaining a biodegradable and biocompatible material which can be metabolized by 
mammals. Only L,L-lactide isomer actually meets these requirements, since it is naturally found in humans (Chen et al., 2003).

Regarding biodegradable polymers, poly(L,L-lactide) (PLLA) has been the subject of much research worldwide (Ceppatelli et al., 2011; Tokiwa et al., 2006; Sosnowski et al., 1996; Lee et al., 2000; Ma et al., 2005). This fact is related to the wide range of products that can be synthesized from PLLA, showing variations in their chemical and physical properties. This flexibility allows that this material has physical properties suitable for a variety of applications, being a viable alternative to front plastics derived from petroleum (Ceppatelli et al., 2011; Langer et al., 1990). The PLLA is a polymeric material renewable, biodegradable, hydrophobic, semicrystalline and unstable in humid conditions, odorless, non-volatile and is rated as safe by the Food and Drug Administration (Datta et al., 1995; Rissanen et al., 2008).

Due to the great current interest in the polymerization reaction, production of polymeric micro and nanoparticles, polymeric particle coating, impregnation of active compounds into polymeric films, the knowledge of phase behaviour between monomers, polymers and supercritical fluids is needed to develop new industrial applications (Bender et al., 2010). Furthermore, the location of the phase boundary for the monomers-supercritical fluid systems plays an important role to establish appropriate reaction conditions. Phase equilibrium data of the L-lactide monomer and of L-Lactic-acid-based polymers of low molecular weight in supercritical carbon dioxide have been reported (Gregorowicz and Bernatowicz, 2009; Gregorowicz, 2008). Gregorowicz (2008) reporting the phase behaviour of L-lactide in supercritical carbon dioxide under high pressure. The solid-fluid (SFE) and liquid-vapor equilibrium (LVE) were observed in the temperature and pressure range of $275-355 \mathrm{~K}$ and $10-80 \mathrm{MPa}$, respectively (Gregorowicz, 2008). However, to our knowledge, data on the phase behaviour of L-lactide and propane in the presence of a co-solvent are not found in the literature. Considering the fact that the addition of a co-solvent may considerably decrease the phase transition pressures and enhance the mass transfer of the system, ethanol was used as a co-solvent in this work because it is a "green" solvent, may be produced from renewable sources. In this scenario, this study investigates the phase equilibrium behavior of the systems propane $+\mathrm{L}, \mathrm{L}-$ lactide at two different ethanol to monomer ratios (9:1 and 7:1 molar ratio).

\section{Experimental}

\subsection{Materials}

Samples of monomer L,L-lactide (CAS\#4511-42-6) was purchased from Sigma-Aldrich (minimum purity of 98\%), used without further purification and stored under nitrogen atmosphere. The water content was measured by the Karl Fischer titration method (Mettler Toledo Model DL 50) resulting in $0.6 \mathrm{wt} \%$ for the L,L-lactide. The solvent propane (minimum mass fraction purity of $99.5 \%$ in the liquid phase) was purchased from White Martins S.A. (Brazil). Ethanol was used as a co-solvent (Merk KGaA, $99.9 \%$ purity). 


\subsection{Apparatus and procedure}

The applied method of measurement is based on detection of phase transitions for constant composition mixtures as a function of pressure and temperature (isopleths). The heart of the apparatus is a high-pressure variable-volume view cell. It is constructed of stainless steel which ensures strength. This experimental apparatus and procedure have been used in a variety of studies (Bender et al., 2010 a, b; Dariva et al., 2001) and was extensively validated (Stuart et al., 2000; Borges et al., 2007). To facilitate the understanding of the effect of ethanol to in the system, the ternary system (propane + ethanol + L,L-lactide) was presented as a pseudo-binary system \{propane(1) + L,L-lactide(2)\} ethanol free-basis at two different molar ratios of ethanol to L,Llactide. The experimental phase equilibrium data were obtained in the temperature range of 323 $353 \mathrm{~K}$ and pressures up to $3.2 \mathrm{MPa}$; the investigated molar ratio of ethanol to L,L-lactide was kept constant at 9:1 and 7:1, corresponding to the following mass ratios: 2.9:1 and 2.2:1, respectively. The overall molar fraction $\left(\mathrm{x}_{1}\right)$ of the pseudo-binary system $\{$ propane $(1)+\mathrm{L}, \mathrm{L}-\mathrm{lactide}(2)\}$, in ethanol free-basis, was varied from 0.500 to 0.978 and 0.500 to 0.971 for the molar ratios of $9: 1$ and 5:1, respectively. The uncertainty in pressure measurements was approximately $0.06 \mathrm{MPa}$, whereas the uncertainty in temperature of the mixture inside the cell was $0.5 \mathrm{~K}$. Based on the uncertainty associated with propane loadings and weighing of the other compounds, we estimate that the uncertainties associated with the global concentrations of the mixtures are lower than $0.5 \%$ on a weight basis.

\section{Results and discussion}

Tables 1 and 2 show the experimental phase transition data measured for the pseudo-binary system \{Propane(1) + L,L-lactide(2)\}, in ethanol free-basis, at two different ethanol to L,L-lactide molar ratios, 9:1 and 7:1, respectively. These tables depict the equilibrium results in terms of pressure, experimental error for each condition represented by the standard deviation of replicate pressure measurements $(\sigma)$, and the phase transition type of phase equilibrium. To improve visualization and interpretation of the phase behavior, Figures 1 and 2 present the experimental data in the form of P-x diagrams for the different isotherms studied. As can be seen from these figures, regardless the propane concentration range and the temperature studied, only vapor-liquid equilibrium (VLE) was found, with bubble point (BP) transition type, as characterized by the formation of bubbles from the bottom of the equilibrium cell during system depressurization. Moreover, for all investigated isotherms, it can be observed that an increase in propane composition and/or a raise in temperature lead to higher pressure transition values. It should also be noted, Table 1 and 2, that the pressure transition observed at all ethanol to L,L-lactide molar ratios investigated, 9:1 and 7:1, in this work are relatively low - the maximum pressure (3.04MPa) was observed, Table 2, at $353 \mathrm{~K}, \mathrm{x}_{1}=0.971$ and ethanol to L,L-lactide molar ratio of 7:1.

For the experimental data at 9:1 ethanol to monomer molar ratio (Table 1 and Figure 1), the temperature and the molar fraction $\left(\mathrm{x}_{1}\right)$ range investigated were 323 to $353 \mathrm{~K}$ and 0.500 to 0.978 , respectively. For propane molar fractions above 0.750 it was not possible to obtain an homogeneous, single phase region at $343 \mathrm{~K}$ and pressures up to $23 \mathrm{MPa}$, which is of course a consequence of the very poor solubility of L,L-lactide in propane. 
Table 1 - Phase equilibrium results for the pseudo-binary system \{propane(1)+L,Llactide(2)\}, ethanol free-basis at ethanol to L,L-lactide molar ratio of 9:1.

\begin{tabular}{|c|c|c|c|c|c|c|c|}
\hline$T / K^{\mathrm{a}}$ & $\mathrm{p} / \mathrm{MPa}^{\mathrm{b}}$ & $\sigma / \mathrm{MPa}^{\mathrm{c}}$ & $\begin{array}{c}\text { Transition } \\
\text { type }^{d}\end{array}$ & $\mathbf{T} / \mathbf{K}^{\mathrm{a}}$ & $\mathrm{p} / \mathrm{MPa}^{\mathrm{b}}$ & $\sigma / \mathrm{MPa}^{\mathrm{c}}$ & $\begin{array}{c}\text { Transition } \\
\text { type }^{d}\end{array}$ \\
\hline \multicolumn{4}{|c|}{$x_{1}^{e}=0.500\left(x_{2}=0.500\right)$} & \multicolumn{4}{|c|}{$x_{1}=0.923\left(x_{2}=0.077\right)$} \\
\hline 323 & 0.74 & 0.07 & VLE & 333 & 2.01 & 0.02 & VLE \\
\hline 333 & 0.80 & 0.08 & VLE & 343 & 2.46 & 0.04 & VLE \\
\hline 343 & 0.92 & 0.02 & VLE & 353 & 2.82 & 0.06 & VLE \\
\hline 353 & 1.00 & 0.04 & VLE & \multicolumn{4}{|c|}{$x_{1}=0.937\left(x_{2}=0.063\right)$} \\
\hline \multicolumn{4}{|c|}{$x_{1}=0.666\left(x_{2}=0.334\right)$} & 333 & 2.00 & 0.02 & VLE \\
\hline 323 & 1.19 & 0.06 & VLE & 343 & 2.50 & 0.04 & VLE \\
\hline 333 & 1.36 & 0.02 & VLE & 353 & 2.86 & 0.06 & VLE \\
\hline 343 & 1.48 & 0.01 & VLE & \multicolumn{4}{|c|}{$x_{1}=0.950\left(x_{2}=0.050\right)$} \\
\hline 353 & 1.70 & 0.03 & VLE & 333 & 2.00 & 0.01 & VLE \\
\hline \multicolumn{4}{|c|}{$x_{1}=0.750\left(x_{2}=0.250\right)$} & 343 & 2.50 & 0.01 & VLE \\
\hline 323 & 1.35 & 0.03 & VLE & 353 & 2.90 & 0.02 & VLE \\
\hline 333 & 1.65 & 0.04 & VLE & \multicolumn{4}{|c|}{$x_{1}=0.971\left(x_{2}=0.029\right)$} \\
\hline 343 & 1.80 & 0.04 & VLE & 333 & 2.01 & 0.01 & VLE \\
\hline 353 & 2.10 & 0.08 & VLE & 343 & 2.52 & 0.01 & VLE \\
\hline \multicolumn{4}{|c|}{$x_{1}=0.800\left(x_{2}=0.200\right)$} & 353 & 3.00 & 0.01 & VLE \\
\hline 333 & 1.81 & 0.03 & VLE & \multicolumn{4}{|c|}{$x_{1}=0.978\left(x_{2}=0.022\right)$} \\
\hline 343 & 2.00 & 0.02 & VLE & 333 & 2.02 & 0.02 & VLE \\
\hline 353 & 2.35 & 0.01 & VLE & 343 & 2.52 & 0.02 & VLE \\
\hline \multicolumn{4}{|c|}{$x_{1}=0.857\left(x_{2}=0.143\right)$} & 353 & 3.02 & 0.01 & VLE \\
\hline 333 & 1.96 & 0.03 & VLE & & & & \\
\hline 343 & 2.21 & 0.04 & VLE & & & & \\
\hline 353 & 2.57 & 0.09 & VLE & & & & \\
\hline \multicolumn{4}{|c|}{$x_{1}=0.900\left(x_{2}=0.100\right)$} & & & & \\
\hline 333 & 2.00 & 0.05 & VLE & & & & \\
\hline 343 & 2.37 & 0.05 & VLE & & & & \\
\hline 353 & 2.72 & 0.09 & VLE & & & & \\
\hline
\end{tabular}

${ }^{\mathrm{a}} \mathrm{T}$, system temperature.

${ }^{\mathrm{b}} \mathrm{P}$, system pressure.

${ }^{c} \sigma$, standard deviation.

${ }^{\mathrm{d}} \mathrm{V}$, vapour phase; L, Liquid phase; E, equilibrium - type BP, Bubble point.

e $x_{1}$, denotes the molar fraction of propane on a ethanol free-basis.

In the 7:1 molar ratio, Table 2 and Figure 2, above propane molar fraction of 0.95 a liquidliquid miscibility was observed at first but it disappears with time (about $4 \mathrm{~h}$ ), resulting in vaporliquid phase transition. This behavior might be related to the following facts: i) mass transfer limitations, which is common for systems showing low (mutual) solubility between the constituents and, ii) possible reaction taking place to form L,L-lactide oligomers. According to Gupta et al. (Chen et al., 2003) ethanol can act as a co-initiator for the polymerization reaction, favoring the formation of oligomers or even low molecular weight polymers. In fact, Ceppatelli et 
al. (Ceppatelli et al., 2011) showed that L,L-lactide at liquid state at elevated temperatures and pressures can react occurring complete transformation to poly(L,L-lactide) and observed that an increase in pressure increases the reaction rate.

Table 2 - Phase equilibrium results for the pseudo-binary system \{propane(1)+L,Llactide(2)\}, ethanol free-basis at ethanol to L,L-lactide molar ratio of 7:1.

\begin{tabular}{|c|c|c|c|c|c|c|c|}
\hline $\mathbf{T} / \mathbf{K}$ & $\mathbf{p} / \mathbf{M P a}$ & б/MPa & $\begin{array}{c}\text { Transition } \\
\text { type }\end{array}$ & $\mathbf{T} / \mathbf{K}$ & $\mathbf{p} / \mathbf{M P a}$ & б/MPa & $\begin{array}{c}\text { Transition } \\
\text { type }\end{array}$ \\
\hline \multicolumn{4}{|c|}{$x_{1}=0.500\left(x_{2}=0.500\right)$} & \multicolumn{4}{|c|}{$x_{1}=0.937\left(x_{2}=0.063\right)$} \\
\hline 333 & 0.95 & 0.03 & VLE & 333 & 2.10 & 0.03 & VLE \\
\hline 338 & 1.00 & 0.06 & VLE & 338 & 2.20 & 0.04 & VLE \\
\hline 343 & 1.13 & 0.02 & VLE & 343 & 2.24 & 0.02 & VLE \\
\hline 353 & 1.30 & 0.01 & VLE & 353 & 3.01 & 0.06 & VLE \\
\hline \multicolumn{4}{|c|}{$x_{1}=0.666\left(x_{2}=0.334\right)$} & \multicolumn{4}{|c|}{$x_{1}=0.950\left(x_{2}=0.050\right)$} \\
\hline 333 & 1.40 & 0.02 & VLE & 333 & 2.10 & 0.03 & VLE \\
\hline 338 & 1.50 & 0.03 & VLE & 338 & 2.44 & 0.02 & VLE \\
\hline 343 & 1.66 & 0.03 & VLE & 343 & 2.48 & 0.06 & VLE \\
\hline 353 & 1.95 & 0.04 & VLE & 353 & 3.03 & 0.04 & VLE \\
\hline \multicolumn{4}{|c|}{$x_{1}=0.750\left(x_{2}=0.250\right)$} & \multicolumn{4}{|c|}{$x_{1}=0.960\left(x_{2}=0.040\right)$} \\
\hline 333 & 1.62 & 0.03 & VLE & 333 & 2.14 & 0.03 & VLE \\
\hline 338 & 1.80 & 0.02 & VLE & 338 & 2.27 & 0.01 & VLE \\
\hline 343 & 1.96 & 0.02 & VLE & 343 & 2.52 & 0.01 & VLE \\
\hline 353 & 2.30 & 0.04 & VLE & 353 & 3.03 & 0.01 & VLE \\
\hline \multicolumn{4}{|c|}{$x_{1}=0.800\left(x_{2}=0.200\right)$} & \multicolumn{4}{|c|}{$x_{1}=0.971\left(x_{2}=0.029\right)$} \\
\hline 333 & 1.72 & 0.04 & VLE & 333 & 2.13 & 0.02 & VLE \\
\hline 338 & 1.91 & 0.03 & VLE & 338 & 2.32 & 0.02 & VLE \\
\hline 343 & 2.15 & 0.01 & VLE & 343 & 2.55 & 0.01 & VLE \\
\hline 353 & 2.50 & 0.03 & VLE & 353 & 3.04 & 0.03 & VLE \\
\hline \multicolumn{4}{|c|}{$x_{1}=0.860\left(x_{2}=0.140\right)$} & & & & \\
\hline 333 & 1.91 & 0.02 & VLE & & & & \\
\hline 338 & 2.05 & 0.03 & VLE & & & & \\
\hline 343 & 2.28 & 0.06 & VLE & & & & \\
\hline 353 & 2.70 & 0.04 & VLE & & & & \\
\hline \multicolumn{4}{|c|}{$x_{1}=0.900\left(x_{2}=0.100\right)$} & & & & \\
\hline 333 & 2.00 & 0.02 & VLE & & & & \\
\hline 338 & 2.70 & 0.01 & VLE & & & & \\
\hline 343 & 2.42 & 0.03 & VLE & & & & \\
\hline 353 & 2.89 & 0.01 & VLE & & & & \\
\hline
\end{tabular}




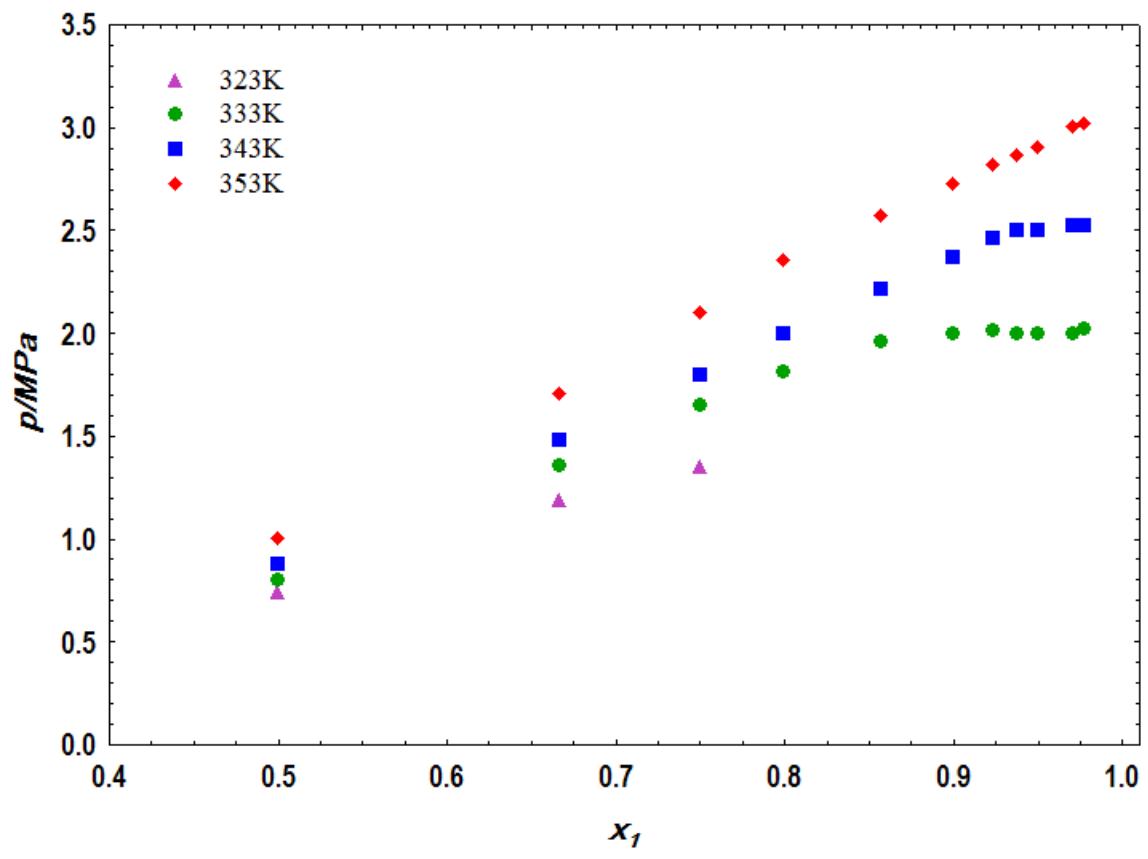

Figure 1 - Pressure-composition diagram for the pseudo-binary system \{propane(1) + L,Llactide(2) $\}$ for ethanol to L,L-lactide molar ratio of 9:1 at $\mathrm{T}=323 ; 333 ; 343$ and $353 \mathrm{~K}$.

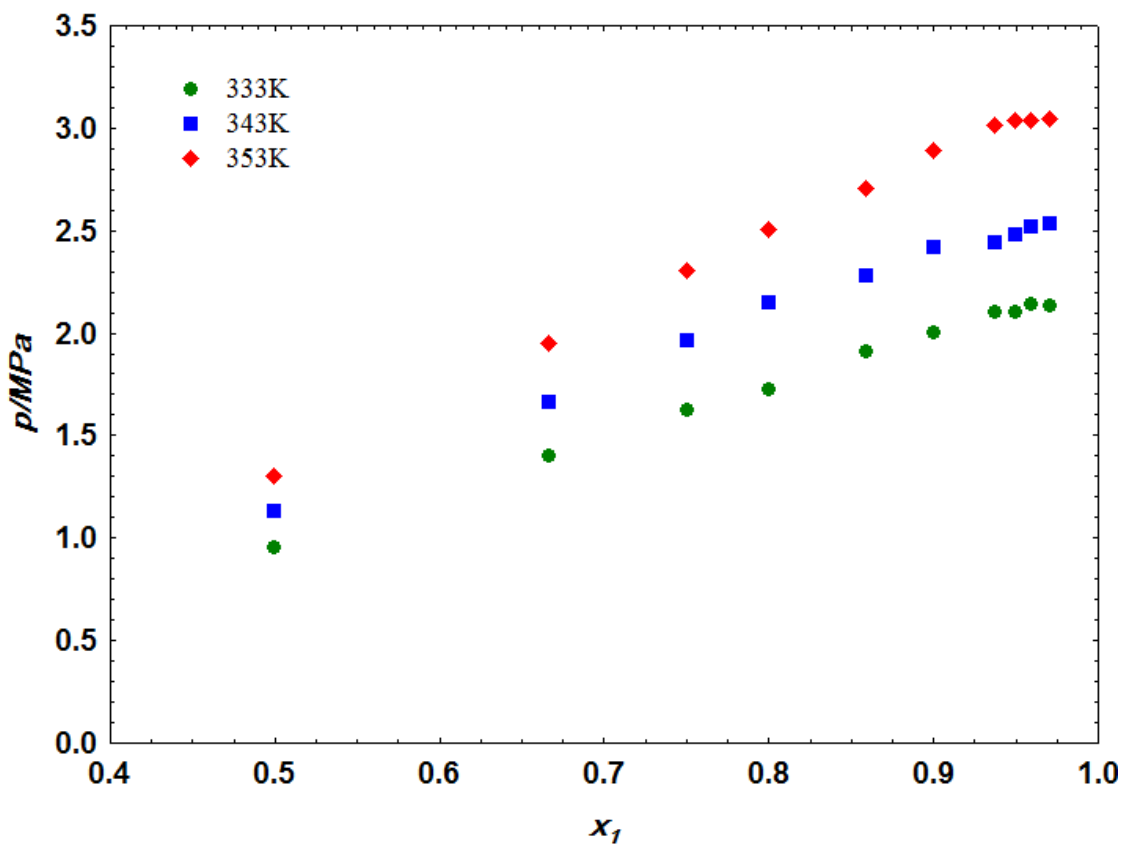

Figure 2 - Pressure-composition diagram for the pseudo-binary system \{propane(1) + L,Llactide(2) $\}$ for ethanol to L,L-lactide molar ratio of 7:1 at $\mathrm{T}=333 ; 343$ and $353 \mathrm{~K}$. 


\section{CONCLUSION}

Phase behavior of the pseudo-binary system propane(1) + L,L-lactide(2) at different ethanol to L,L-lactide molar ratios (9:1 and 7:1) was experimentally investigated in this work over the temperature range of ( 323 to $353 \mathrm{~K}$ ) in a wide overall composition range of the lightest compound, resulting in phase transition pressures up to $3.04 \mathrm{MPa}$. For all systems, independent on the concentration range of propane and temperature investigated, only vapor-liquid equilibrium (VLE) was observed with bubble point (BP) type transitions. For all investigated isotherms, it was observed that an increase in propane composition and/or an increase in system temperature, led to higher pressure transition values.

\section{REFERENCIAS}

AVÉROUS, L. Polylactic Acid: Synthesis, Properties and Applications. Monomers, Polymers and Composites from Renewable Resources, c. 21, p. 433-450, 2008.

BENDER, J. P.; FEITEIN, M.; MAZUTTI, M. A.; FRANCESCHI, E.; CORAZZA, M. L. OLIVEIRA, J. V. Phase behaviour of the ternary system \{poly(-caprolactone) + carbon dioxide + dichloromethane\}. Journal of Chemical Thermodynamics, v. 42 p. 229-233, 2010.

BENDER, J. P.; FEITEN, M.; FRANCESCHI, E.; CORAZZA, M. L.; OLIVEIRA, J. V. Phase behaviour of binary systems of lactones in carbon dioxide. $J$. Chem.Thermodynamics, v. 42, p. 48-53, 2010.

BORGES, G. R.; JUNGES, A.; FRANCESCHI, E.; CORAZZA, F. C.; CORAZZA, M. L.; OLIVEIRA, J. V.; DARIVA, C. High-pressure vapor-liquid equilibrium data for systems involving carbon dioxide + organic solvent $+\beta$-carotene, Journal of Chemical Engineering Data, v. 52, p. 1437-1441, 2007.

CEPPATELlI, M.; FREDIANI, M.; BINI, R. High-Pressure Reactivity of L,L-Lactide. Journal of Physical Chemistry B., v. 115, p. 2173-2184, 2011.

CHEN, C. C.; CHUEH, J. Y.; TSENG, H.; HUANG, H. M.; LEE, S. Y. Preparation and characterization of biodegradable PLA polymeric blends. Biomaterials v. 24, p. 11671173, 2003.

DARIVA, C.; PINTO, J. C.; TAVARES, F. W.; OLIVEIRA, J. V. Phase behavior of polypropylene samples with hydrocarbon solvents at high pressures. J. Appl. Pol. Sci., v. 81 p. $3044-3055,2001$. 
DATTA, R.; Tsai, S. -P. Bonsignore, P.; Moon, S. -H.; Frank, J. R. Technological and economic potential of poly(lactic acid) and lactic acid derivatives. FEMS Microbiology Reviews, v. 16, p. 221-231, 1995.

GREGOROWICZ, J. Phase behaviour of L-lactide in supercritical carbon dioxide at high pressures. Journal of Supercritical Fluids, v. 46, p. 105-111, 2008.

GREGOROWICZ, J.; BERNATOWICZ, P. Phase behaviour of L-lactic acid based polymers of low molecular weight in supercritical carbon dioxide at high pressures, Journal of Supercritical Fluids, v. 51, p. 270-277, 2009.

GUPTA, A. P.; KUMAR, V. New emerging trends in synthetic biodegradable polymers Polylactide: A critique. European Polymer J., v. 43, p. 4053-4074, 2007.

LANGER, M.; Brown, R.; Urie, M.; Leong, J.; Stracher, M.; Shapiro, J. Large scale optimization of beam weights under dose-volume restrictions. Int. J. Radiat. Oncol. Biol. Phys., v. 18, p. 887-893, 1990.

LEE, J. M.; LEE, B. Phase Behavior of Poly(L-lactide) in Supercritical Mixtures of. J. Chem. Eng. Data, v. 45, p. 1162-1166, 2000.

LOPEZ-LUNA, A.; GALLEGOS, J. L.; GIMENO, M.; VIVALDO-LIMA, E.; BÁRZANA, E. Lipase-catalyzed syntheses of linear and hyperbranched polyesters using compressed fluids as solvent media, Journal of Molecular Catalysis B: Enzymatic, v. 67, p. 143-149, 2010 .

MA, H.; OKUDA, J. Kinetics and Mechanism of L-Lactide Polymerization by Rare Earth Metal Silylamido Complexes: Effect of Alcohol Addition. Macromolecules, v. 38, p. 2665-2673, 2005.

RISSANEN, M.; Puolakka, A.; Nousiainen, P.; Kellomäki, M.; Ellä V. Solubility and phase separation of poly(L,D-lactide) copolymers. Journal of Appied Polymer Science, v. 110, p. 2399-2404, 2008.

SOSNOWSKI, S.; GADZINOWSKI, M.; SLOMKOWSKI, S. Poly(L,L-lactide) Microspheres by Ring-Opening Polymerization. Macromolecules, v. 29, p. 4556-4564, 1996.

STUART, G. R.; DARIVA, C.; OLIVEIRA, J. V. High-pressure vapor-liquid equilibrium data for CO2-orange peel oil, Brazilian Journal of Chemical Engineering, v. 17 p. 181$189,2000$.

TOKIWA, Y.; CALABIA, B. P. Biodegradability and biodegradation of poli(lactide). Applied Microbiology and Biotechnology, v. 72, p. 244-251, 2006. 